\title{
The effect of indole-butyric acid and kinetin on rooting of rose cuttings in winter and summer
}

\author{
EDWARD BOROWSKI, LIDIA KOZLOWSKA, MARIA WILKOWICZ
}

\author{
Institute of Natural Principles of Plant Production, Agricultural Academy, Akademicka 15, \\ 20-934 Lublin, Poland \\ (Received: June 25, 1984)
}

\begin{abstract}
The effect of indole-butyric acid, both alone and with a low concentration of kinetin, on the rooting of rose cuttings in winter and summer, is presented in this paper. The experiments were conducted using 500 and $1000 \mathrm{mg} / 1$ IBA with or without the addition of $5 \mathrm{mg} / 1$ kinetin. The growth regulators were applied by dipping the base of a cutting for $5 \mathrm{~s}$ in an aqueous solution of these substances. Cuttings $5-6 \mathrm{~cm}$ in length were made from the mid-part of a stem of a rose grown in a greenhouse. The experiments were carried out using 'Queen of Bermuda' and 'Baccara' cuttings. The investigations showed that treating rose cuttings rooted in winter with an IBA solution had a significant promotive effect on the quantity of rooted cuttings, number of formed roots on the cutting, as well as on the length of the longest root. A distinctive increase in the number of breaking buds was also seen on the cuttings treated with IBA. The IBA solution applied to cuttings rooted in the summer significantly decreased the number of rooted cuttings and breaking buds. However, no significant influence on the number and length of formed roots was found. Addition of kinetin to the IBA solutions did not have any effect on the rooting of rose cuttings either in winter or summer.
\end{abstract}

\section{INTRODUCTION}

Roses are most commonly propagated vegetatively by budding on stocks obtained through selection from wildly growing species - Rosa canina L. and Rosa multiflora Thumb. This way of propagating roses is very work-consuming, lengthy and does not always produce planting material of the appropriate quality. For these teasons, for the last 10-old years, in Western Europe and USSR and also recently in Poland, studies have been undertaken to propagate roses by cuttings (Tite and Allen, 1969; Marston et al., 1969; Moe, 1971; Moe, 1973; Bhujbal and Kale, 1973; Saakov and Rieksta, 1973; Szendel et al., 1977).

Up until now, most of the studies on propagating roses by cuttings have been done in the summer, that is, from June to September. Since summer is usually an unfavorable period for vegetative propagation of plants, it seemed purposeful to undertake studies on the possibility of multiplying roses by cuttings during the 
winter. This would allow the cuttings to be made from appropriately developed stems, which often go to waste when cut from bushes being prepared for winter dormancy. The cuttings rooted in winter would then have the opportunity to intensively grow during the coming spring and would begin to bloom still in the same year.

In the experiments, IBA at concentrations of 500 and $1000 \mathrm{mg} / \mathrm{l}$, and the combined action of both relatively high concentrations of IBA with a low concentration of kinetin, were studied. Additionally, the effectiveness of winter and summer rooting were compared. From the few existing studies on rooting rose cuttings (Moe, 1971; Szendel et al., 1977) it can be seen that from among auxins, IBA has the most favorable effect on the process of rhizogenesis. In Heide's opinion (1965), the effect of auxins on the rooting of cuttings of several plants may be increased by applying them along with a low concentration of cytokinins.

\section{MATERIAL AND METHODS}

The experiments were carried out at the Zakład Produkcji Szklarniowej (Greenhouse Production Company) in Leonów near Lublin. The studies were done on rose cuttings from the 'Queen of Bermuda' and 'Baccara' varieties made from year-old stems of roses grown in the production greenhouse. The cuttings were made only from the middle parts of stems which were entering the blooming phase. The upper cut was made approximately $1 \mathrm{~cm}$ above a bud in a leaf corner, the lower, about 5-6 cm below. In this way, one-noded cuttings which had one, healthy, well-formed leaf, were obtained. Immediately after cutting, the bases of the cuttings were immersed to a depth of $10 \mathrm{~mm}$ in an aqueous solution of the appropriate growth substances. The following growth substances were used in the experiments: IBA $500 \mathrm{mg} / 1$; IBA $1000 \mathrm{mg} / 1$; IBA $500 \mathrm{mg} / 1+$ kinetin $5 \mathrm{mg} / 1$; IBA $1000 \mathrm{mg} / 1$ +kinetin $5 \mathrm{mg} / 1$. The control cuttings were immersed in distilled water. The cuttings were treated with the growth substances or water for $5 \mathrm{~s}$. After being removed from the solution, the cuttings were placed in a rack until they dried, after which they were put into plastic containers with a lattice bottom, filled with a mixture of perlit and peat at a ratio of $3: 1$. The depth of the bed layer in the box was $15 \mathrm{~cm}$. The cuttings were planted at a depth of $4-5 \mathrm{~cm}$, spaced $5 \times 12 \mathrm{~cm}$ apart.

The containers with the cuttings were placed in the greenhouse and, additionally, covered for the first three weeks with a plastic foil tent. During rooting, the following conditions were maintained: natural lighting, air temperature in winter about $20^{\circ} \mathrm{C}$, in summer - depending on the temperature of the surroundings, air humidity about $90 \%$ f.w.c. especially during the first weeks of rooting. Five combinations were made during the experiment. In each, 30 cuttings in two repetitions were examined.

The cuttings were rooted for six weeks, both during the winter and summer. The winter experiments were carried out from Dec. 8 to Jan. 19 of 1981/1982 and 1982/1983. The summer experiments were done from June 22 to Aug. 3 in 1982 
and 1983. After 6 weeks of rooting, the experiment was liquidated. This was done by delicately removing the cutting along with the whole root clump from the box, and then the soil was separated from the roots with water. After the roots were delicately washed, their number (per cutting) was determined and the longest root in each root system was measured. After all of the cuttings in a given combination were examined, the percentage of rooted cuttings and of cuttings in which the buds in the leaf corners had begun to develop during rooting, were determined. The percentages were calculated on the basis of the entire number of cuttings in the combination. The average number of roots per cutting and the average length of the longest root in both of the studied varieties were analyzed statistically, using the complete randomization system and Tuke's range of confidence.

\section{RESULTS}

\section{A. Rooting of rose cuttings in winter}

The results obtained in this study clearly indicate that winter is an unfavorable period for rooting of rose cuttings. In both of the studied years, the percentage of rooted cuttings in the control groups for the 'Queen of Bermuda' variety did not exceed 50, for 'Baccara' - 33.3. The root system formed under these conditions was characterized by a small number of relatively short roots (Table 1, 2). The cuttings rooted in winter did not show a tendency for further development, which was shown by the sporadic development of buds in leaf corners.

Table 1

The effect of indole-butyric acid (IBA) alone and jointly with kinetin on the rooting of "Queen of Bermuda" rose cuttings in winter

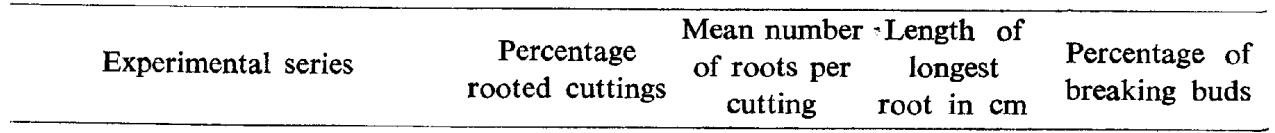

$1981 / 1982$

\begin{tabular}{lcrrr} 
Control & 40.0 & 3.4 & 3.4 & 6.7 \\
IBA $500 \mathrm{mg} / \mathrm{l}$ & 70.0 & 9.7 & 7.2 & 46.7 \\
IBA $1000 \mathrm{mg} / \mathrm{l}$ & 83.3 & 23.7 & 8.6 & 66.7 \\
IBA $500 \mathrm{mg} / \mathrm{l}+$ kinetin $5 \mathrm{mg} / \mathrm{l}$ & 86.7 & 12.3 & 7.8 & 60.0 \\
IBA $1000 \mathrm{mg} / \mathrm{l}+$ kinetin $5 \mathrm{mg} / \mathrm{l}$ & 86.7 & 23.2 & 8.1 & 83.3 \\
\hline LSD at $0.95 \%$ & - & 7.09 & 1.57 & - \\
\hline 1982/1983 & & & & \\
Control & & & & 30.0 \\
IBA $500 \mathrm{mg} / 1$ & 50.0 & 4.0 & 4.4 & 46.7 \\
IBA $1000 \mathrm{mg} / 1$ & 73.3 & 12.8 & 8.4 & 56.7 \\
IBA $500 \mathrm{mg} / 1+$ kinetin $5 \mathrm{mg} / \mathrm{l}$ & 76.7 & 19.4 & 8.0 & 56.7 \\
IBA $1000 \mathrm{mg} / \mathrm{l}+$ kinetin $5 \mathrm{mg} / 1$ & 80.0 & 14.6 & 7.3 & 70.0 \\
\hline LSD at $0.95 \%$ & 86.7 & 21.9 & 7.7 & - \\
\hline
\end{tabular}


Table 2

The effect of indole-butyric acid (IBA) alone and jointly with kinetin on the rooting of 'Baccara' rose cuttings in winter

\begin{tabular}{|c|c|c|c|c|}
\hline Experimental series & $\begin{array}{c}\text { Percentage } \\
\text { rooted cuttings }\end{array}$ & $\begin{array}{l}\text { Mean number } \\
\text { of roots per } \\
\text { cutting }\end{array}$ & $\begin{array}{c}\text { Length of } \\
\text { longest root } \\
\text { in } \mathrm{cm}\end{array}$ & $\begin{array}{l}\text { Percentage of } \\
\text { breaking buds }\end{array}$ \\
\hline \multicolumn{5}{|l|}{$1981 / 1982$} \\
\hline Control & 26.7 & 5.6 & 2.9 & 13.3 \\
\hline IBA $500 \mathrm{mg} / 1$ & 53.3 & 16.4 & 6.8 & 33.3 \\
\hline IBA $1000 \mathrm{mg} / 1$ & 60.0 & 27.1 & 7.1 & 36.7 \\
\hline IBA $500 \mathrm{mg} / 1+$ kinetin $5 \mathrm{mg} / 1$ & 66.7 & 17.2 & 7.0 & 40.0 \\
\hline IBA $1000 \mathrm{mg} / 1+$ kinetin $5 \mathrm{mg} / 1$ & 76.7 & 29.5 & 7.5 & 46.7 \\
\hline LSD at $0.95 \%$ & - & 8.03 & 1.64 & - \\
\hline \multicolumn{5}{|l|}{$1982 / 1983$} \\
\hline Control & 33.3 & 7.1 & 3.8 & 23.3 \\
\hline IBA $500 \mathrm{mg} / 1$ & 56.7 & 15.8 & 8.3 & 46.7 \\
\hline IBA $1000 \mathrm{mg} / \mathrm{l}$ & 66.7 & 25.7 & 7.7 & 53.3 \\
\hline IBA $500 \mathrm{mg} / \mathrm{l}+$ kinetin $5 \mathrm{mg} / \mathrm{l}$ & 70.0 & 18.3 & 8.6 & 50.0 \\
\hline IBA $1000 \mathrm{mg} / 1+$ kinetin $5 \mathrm{mg} / 1$ & 73.3 & 28.1 & 8.8 & 60.0 \\
\hline LSD at $0.95 \%$ & - & 6.82 & 1.69 & - \\
\hline
\end{tabular}

This unfavorable effect of winter on rooting was clearly improved when indole3-butyric acid was used (Fig. 1). IBA at a dose of $500 \mathrm{mg} / 1$ increased almost twice the number of rooted cuttings and the growth of roots as judged by the length of the longest root. The effect of the auxin on the average number of formed roots and the percentage of breaking buds in leaf corners was even more significant. The IBA-treated cuttings produced an average of 3 times more roots. The percent of breaking shoot buds on the 'Baccara' variety cuttings increased under the influence of $500 \mathrm{mg} / 1 \mathrm{IBA}$ nearly 3-fold in 1981/1982 and two-fold in 1982/1983. Whereas, the 'Queen of Bermuda' variety cuttings exhibited a variable increase in the number of breaking buds under the influence of IBA during both years of the study. It was very high during the winter of 1981/1982 (7-fold) and relatively low during the winter of $1982 / 1983$. Increasing the concentration of indole-3-butyric acid from 500 to $1000 \mathrm{mg} / \mathrm{l}$ caused an increase in the number of roots on the cuttings from both varieties (Table 1, 2; Fig. 1). The higher auxin concentration also slightly increased the percentage of rooted cuttings and breaking buds in leaf corners, but had no effect on root growth as evaluated by the length of the longest root of the cutting's root system.

The joint action of both studied IBA concentrations with kinetin $(5 \mathrm{mg} / \mathrm{l})$ increased only to a slight degree, as compared with auxin alone, the percentage of rooted cuttings and breaking buds, whereas no effect was observed on the average number of formed roots and their length (Table 1,2). 


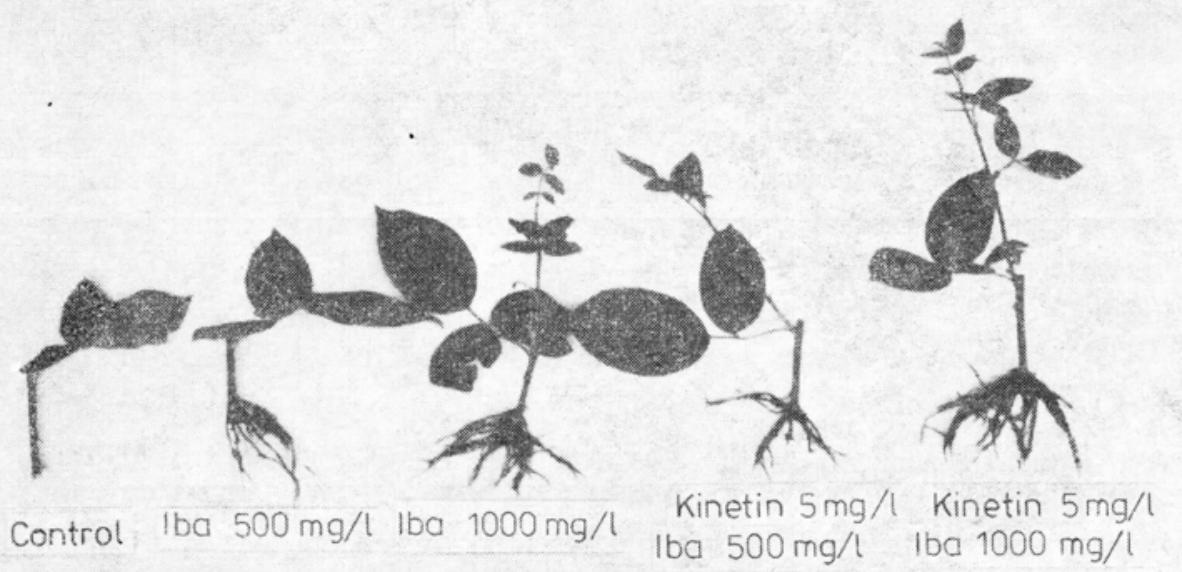

Fig. 1. 'Queen of Bermuda' rose cuttings after rooting in winter

B. Rooting of rose cuttings in the summer

Cuttings from both of the studied varieties rooted completely differently in the summer (Table 3,4). The control cuttings rooted the best, which was shown by the highest percentage of rooted cuttings and breaking stem buds in this group. The control cuttings, that is, those not treated with growth substances, were also characterized by a large number of roots and their good growth.

The use of IBA, especially at the higher concentration $(1000 \mathrm{mg} / \mathrm{l})$ very clearly lowered the percentage of rooted cuttings, as well as the percent of developing buds in leaf corners. The cuttings treated with indole-3-butyric acid at a concentration of $1000 \mathrm{mg} / \mathrm{l}$, rooted, depending on the year, from 2 to even 10 times worse than the control cuttings. The percent of breaking buds was lowered in a similar way $($ Table 3,4$)$. The use of IBA had a much less pronounced effect on the number and length of roots formed on the cuttings. Indole-3-butyric acid induced a slight lowering of the average number of roots formed on cuttings of the 'Queen of Bermuda' variety and a slight increase in the number of roots on cuttings of the 'Baccara' variety. However, this effect on both varieties turned out to be statistically insignificant.

The small addition of kinetin did not counteract the negative effect of IBA on the rooting of rose cuttings in the summer. In a few cases, especially those from the 'Queen of Bermuda' variety, kinetin deepened the negative effect of IBA on the rooting of the cuttings. 
Table 3

The effect of indole-butyric acid (IBA) alone and jointly with kinetin on the rooting of 'Queen of Bermuda' rose cuttings in summer

\begin{tabular}{|c|c|c|c|c|}
\hline Experimental series & $\begin{array}{c}\text { Percentage } \\
\text { of rooted } \\
\text { cuttings }\end{array}$ & $\begin{array}{l}\text { Mean number } \\
\text { of roots per } \\
\text { cutting }\end{array}$ & $\begin{array}{l}\text { Length of } \\
\text { longest root } \\
\text { in } \mathrm{cm}\end{array}$ & $\begin{array}{l}\text { Percentage of } \\
\text { breaking buds }\end{array}$ \\
\hline \multicolumn{5}{|l|}{1982} \\
\hline Control & 73.3 & 18.5 & 6.2 & 80.0 \\
\hline IBA $500 \mathrm{mg} / 1$ & 73.3 & 12.8 & 8.5 & 73.3 \\
\hline IBA $1000 \mathrm{mg} / \mathrm{l}$ & 33.3 & 11.5 & 7.9 & 33.3 \\
\hline IBA $500 \mathrm{mg} / \mathrm{l}+$ kinetin $5 \mathrm{mg} / 1$ & 40.0 & 11.0 & 8.5 & 46.7 \\
\hline IBA $1000 \mathrm{mg} / \mathrm{l}+$ kinetin $5 \mathrm{mg} / \mathrm{l}$ & 33.3 & 15.2 & 8.5 & 33.3 \\
\hline LSD at $0.95 \%$ & \multicolumn{4}{|c|}{ no significant differences } \\
\hline \multicolumn{5}{|l|}{1983} \\
\hline Control & 80.0 & 16.4 & 8.0 & 80.0 \\
\hline IBA $500 \mathrm{mg} / 1$ & 53.3 & 15.7 & 7.3 & 46.7 \\
\hline IBA $1000 \mathrm{mg} / \mathrm{l}$ & 13.3 & 16.5 & 6.9 & 13.3 \\
\hline IBA $500 \mathrm{mg} / 1+$ kinetin $5 \mathrm{mg} / \mathrm{l}$ & 20.0 & 11.3 & 7.5 & 20.0 \\
\hline IBA $1000 \mathrm{mg} / \mathrm{l}+$ kinetin $5 \mathrm{mg} / \mathrm{l}$ & 6.7 & 12.0 & 4.1 & 6.7 \\
\hline LSD at $0.95 \%$ & \multicolumn{4}{|c|}{ no significant differences } \\
\hline
\end{tabular}

\section{Table 4}

The effect of indole-butyric acid (IBA) alone and jointly with kinetin on the rooting of 'Baccara' rose cuttings in summer

\begin{tabular}{lcccc}
\hline \multicolumn{1}{c}{ Experimental series } & $\begin{array}{c}\text { Percentage } \\
\text { of rooted } \\
\text { cuttings }\end{array}$ & $\begin{array}{c}\text { Mean number } \\
\text { of roots per } \\
\text { cutting }\end{array}$ & $\begin{array}{c}\text { Length of } \\
\text { longest root } \\
\text { in cm }\end{array}$ & $\begin{array}{c}\text { Percentage of } \\
\text { breaking buds }\end{array}$ \\
\hline 1982 & & & & \\
Control & 66.7 & 21.6 & 6.9 & 60.0 \\
IBA $500 \mathrm{mg} / 1$ & 20.0 & 23.3 & 8.8 & 13.3 \\
IBA $1000 \mathrm{mg} / 1$ & 6.7 & 25.0 & 8.9 & 6.7 \\
IBA $500 \mathrm{mg} / \mathrm{l}+$ kinetin $5 \mathrm{mg} / 1$ & 40.0 & 27.2 & 5.9 & 40.0 \\
IBA $1000 \mathrm{mg} / 1+$ kinetin $5 \mathrm{mg} / 1$ & 6.7 & 26.0 & 8.3 & 6.7 \\
\hline LSD at $0.95 \%$ & & no significant differences & \\
\hline 1983 & & & & \\
Control & & & & \\
IBA $500 \mathrm{mg} / 1$ & 66.7 & 20.3 & 7.1 & 53.3 \\
IBA $1000 \mathrm{mg} / 1$ & 33.3 & 23.8 & 8.3 & 33.3 \\
IBA $500 \mathrm{mg} / 1+$ kinetin $5 \mathrm{mg} / 1$ & 33.3 & 22.0 & 6.3 & 26.7 \\
IBA $1000 \mathrm{mg} / \mathrm{l}+$ kinetin $5 \mathrm{mg} / 1$ & 46.7 & 24.7 & 7.3 & 33.3 \\
\hline
\end{tabular}




\section{DISCUSSION}

The results of the study presented here clearly point to the different reaction to auxins of rose cuttings rooted in winter and summer. The use of IBA was beneficial for rooting in winter whereas its use in summer had a clearly negative effect. The favorable effect of using auxins on cuttings rooted in winter is probably connected with the level of endogenous auxins contained in the shoots of roses growing in winter. The short day, low light intensity as well as the lower temperatures in the greenhouse during winter than in the summer, are factors which, according to Moe (1971), clearly lower the level of endogenous auxins in rose shoots. A similar effect of the amount of daylight and temperature on the content of endogenous auxins in plants was also observed by Heide (1967) in begonias and Tillberg (1974) in beans. The low level of endogenous auxins in rose stems during winter was the factor determining the poor rooting of cuttings during this period. Under these conditions, raising the auxin content in cuttings by administering it in the form of IBA, had a favorable effect on the process of rooting. This effect was all the more clear the higher were the auxin concentrations used. Whereas, in the summer, when the lighting conditions in the greenhouse are more favorable, the level of endogenous auxins in the shoots of the studied rose varieties was presumably much higher and near the optimum for rooting. That is why applying exogenous auxin, even at the lowest concentration used, raised the auxin level to above optimum, and had an unfavorable effect on the rooting of cuttings. The negative effect of the high auxin concentration, given in the form of IBA, on the rooting of rose cuttings in summer was also found by Szendel et al. (1977). Marston et al. (1969) showed that rose cuttings rooted in June and September formed root systems without the aid of rooting hormones. Administration of hormones in the form of 'Seradix' had no influence on increasing the number of rooted cuttings, but lessened the length of the formed roots. Bhujbal and Kale (1973) and Moe (1973) on the other hand, did not find the negative effect of IBA on the rooting of rose cuttings in summer. It seems that the different effect of exogenously administered auxins in the summer months as well, results from the natural ability of cuttings from a given variety to form roots. The cuttings of the studied varieties, especially 'Queen of Bermuda', belong to easy-to-root varieties, and maybe, this is why they reacted negatively to the administered auxin. Whereas cuttings from varieties which root with more difficulty, probably react more favorably to growth regulators also in the summer.

In the study done here, a different effect of IBA on the development of buds in leaf corners of cuttings rooted in winter and summer, was also observed. During the winter, administration of IBA significantly increased the number of developing buds on the cuttings, whereas in the summer, the effect of IBA was the opposite. This fact seems to confirm the earlier hypothesis about the low endogenous auxin level in rose shoots growing in the winter, and high level in shoots growing in the summer. Moe (1971) and Marston et al. (1969) showed that high auxin concen- 
trations inhibited the development of buds, whereas low concentrations stimulated the development of buds on cuttings.

The favorable effect of joint action of high auxin concentrations with low cytokinin concentrations on root development, used with success in "in vitro" multiplication of plants as well as in rooting of begonia leaf cuttings (Heide, 1965), was not confirmed in this study. The addition of $5 \mathrm{mg} / 1$ kinetin to both IBA concentrations used here did not have a significant effect on the rooting of cuttings or on the development of buds. Also, the use of $5 \mathrm{mg}$ kinetin/1, which was the subject of a separate experiment, the results of which are not presented here, did not have an effect on the rooting of rose cuttings. It seems that the different reaction of rose and begonia cuttings to high auxin concentrations administered along with low cytokinin concentrations could result from the completely different species of the studied plants (roses, begonias), as well as from the different types of cuttings used for multiplication. In the case of begonias - leaf cuttings were used, roses - stem cuttings.

\section{REFERENCES}

Bhujbal B. G., Kale P. N., 1973. Effect of some growth regulators on rooting of cuttings of different rootstocks of rose (Rosa -sp.). Punjab Horticultural Journal 1: 50-53.

Heide O. M., 1965. Interaction of temperature, auxins and kinins in the regeneration ability of begonia leaf cuttings. Physiol. Plant. 18: 891-920.

Heide O. M., 1967. The auxin level of begonia leaves in relation to their regeneration ability. Physiol, Plant. 20: 886-902.

Marston M. E., Crofts J. A., Maxim B. N., Salisbury R. A., 1969. Propagation of roses by cuttings using small amounts of plant material. Experimental Hortic. 20: 14-21.

Moe R., 1971. Kulture von topfrosen nach neven erkenntnissen. Gartenwelt. 13: 295-300.

Moe R., 1973. Propagation, growth and flowering of potted roses. Acta Hort. 31: 35-51.

Saakov S. G., Rieksta O. A., 1973. Rozy. Izdatelstvo Zinatne, Riga. pp. 302-306.

Szendel J. A., Hetman J., Łobanowski J., Tracz A., 1977. Badania nad możliwością rozmnażania róż przez sadzonkowanie. Ogrodnictwo 7: 184.

Tillberg E., 1974. Levels of indol-3yl-acetic acid and acid inhibitors in green and etiolated bean seedlings (Phaseolus vulgaris). Physiol. Plant. 31: 106-111.

Tite R. L., Allen P. G., 1969. Propagation of roses by softwood cuttings. Experimental Hortic. 20: 10-13.

Wpływ kwasu indolilo-masłowego i kinetyny na ukorzenianie się sadzonek róż w okresie zimowym i letnim

\section{Streszczenie}

W pracy przedstawiono wyniki badań dotyczące wpływu kwasu indolilo-masłowego, a także współdziałania tej auksyny z niskim stężeniem kinetyny na ukorzenianie się sadzonek róż w okresie zimowym i letnim. W doświadczeniach zastosowano IBA w stężeniu $500 \mathrm{mg} / 1$ i $1000 \mathrm{mg} / \mathrm{loraz}$ 
mieszaninę każdego z tych stężeń IBA z kinetyną w stężeniu $5 \mathrm{mg} / 1$. Regulatory wzrostu podano przez zanurzenie podstawy sadzonek $w$ wodnych roztworach wymienionych substancji na okres 5 sekund. Sadzonki jednowęzłowe długości $5-6 \mathrm{~cm}$ cięto ze środkowej części pędów róż rosnących w szklarni. Doświadczenia prowadzono na sadzonkach odmiany 'Qeen of Bermuda' i 'Baccara'.

W wyniku przeprowadzonych doświadczeń stwierdzono, że traktowanie roztworem IBA sadzonek róż ukorzenianych zimą wywierało istotnie korzystny wpływ na ilość ukorzenionych sadzonek, liczbę korzeni wykształconych na sadzonce, a także na długość najdłuższego korzenia. $\mathrm{Na}$ sadzonkach traktowanych roztworem IBA wyraźnie zwiększała się liczba wybijających pąków.

Stosowanie roztworu IBA na sadzonki ukorzeniane latem powodowało obniżenie liczby ukorzenionych sadzonek i liczby wybijających pąków na sadzonkach. Natomiast nie obserwowano istotnego wplywu na liczbę i dlugośc wykształconych korzeni.

Dodatek kinetyny do roztworu IBA nie wplywał na przebieg ukorzeniania się sadzonek róż zarówno w okresie zimowym, jak i letnim. 